\title{
Van de redactie
}

De kop is eraf! Voor u ligt het tweede nummer van het Tijdschrift voor Ontslagrecht. Een van de bestaansredenen van $T v O$ is de constante vraag naar duiding van het ontslagrecht binnen de Nederlandse arbeidsverhoudingen vanwege de stevige verwevenheid van het ontslagrecht met de politieke, maatschappelijke en praktische realiteit van alledag.

In februari 2017 presenteerde de Wetenschappelijke Raad voor het Regeringsbeleid (WRR) zijn tweede rapport in het project 'Toekomst van werk' over cruciale marktontwikkelingen. Het eerste rapport verscheen in 2015 en ging over digitalisering en robotisering en de gevolgen voor de arbeidsmarkt. In het tweede rapport staat de toenemende flexibilisering van de arbeidsmarkt en de gevolgen die deze ontwikkeling kan hebben voor economie en samenleving centraal. Het is terecht dat aan dit thema andacht wordt besteed, al is het maar omdat het al langer diverse agenda's beheerst en via het 'Mondriaanakkoord' leidde tot onder andere de Wwz. Ondanks de goede bedoelingen van wetgever en sociale partners over de aanpak van doorgeschoten flex, is de realiteit van vandaag evenwel dat werkgevers werknemers nog steeds niet in vaste dienst nemen en dat Nederland nog steeds koploper flexibele arbeid in Europa is. In het rapport van de WRR wordt naar verklaringen gezocht. Over flexibilisering wordt onder meer opgemerkt dat het niet alleen maar slecht (gebrek aan scholing, levenslooponzekerheid en gebrek aan erkenning) is; flexibele arbeid kan een opstap of overstap naar vaste arbeid vergemakkelijken en de onzekerheid die kenmerkend is voor flexibel werken wordt niet door iedereen op dezelfde manier gevoeld. Kortom, bij werkenden bestaat een zekere behoefte aan flex, al moet die behoefte ook niet overschat worden. De behoefte aan flex is bij werkgevers veel groter, zo lijkt het. Werkgevers ervaren het vaste contract toch veelal als een beperking om flexibel te kunnen inspelen op economische ontwikkelingen die globalisering meebrengt. Zij kiezen daarom vaker voor flexibele arbeidsverhoudingen. Werkgevers zien het ook niet als hun taak de onzekerheid van werknemers te compenseren, zo blijkt uit het rapport van de WRR. Tot slot wordt in het rapport aandacht besteed aan de opkomst van de 'on demand economy' of 'gig economy' die de organisatie van arbeid wezenlijk verandert en die in belangrijke mate bijdraagt aan flexibilisering. In de gig economy worden werkzaamheden die voorheen gezamenlijk een vaste baan vormden, door verschillende handen van een steeds wisselende groep werkenden verricht.

De Tilburgse hoogleraar Wilthagen heeft terecht opgemerkt dat voornoemde ontwikkelingen (individuele behoeftes, globalisering en digitalisering) niet alles kunnen verklaren. Al deze ontwikkelingen spelen immers ook in andere (West-)Europese landen, terwijl het gebruik van flex in die landen veel geringer is dan in Nederland. De invloed van de wet- en regelgeving (inclusief cao's) op de inzet van flex moet niet worden onderschat. Er is vaker op gewezen, maar de arbeidsovereenkomst voor onbepaalde tijd lijkt met name de laatste decennia te zwaar te zijn opgetuigd of belast. Teneinde de doorgeschoten flexibilisering te keren, heeft de wetgever in de $\mathrm{Wwz}$ gekozen voor meer rechtsbescherming van flexwerkers en niet voor de aanpak van het vaste contract. Sterker, veel - met name kleine werkgevers ervaren de $\mathrm{W}_{w z}$ juist als een verzwaring van het vaste contract. Denk daarbij onder andere aan het limitatieve grondenstelsel (en daaraan verbonden thema's als herplaatsing), de mogelijkheid van hoger beroep en cassatie (en toepassing van het bewijsrecht), de bedenktermijn en de verplicht gestelde transitievergoeding. In dit nummer vindt $u$ een aantal mooie bijdragen over deze onderwerpen.

De eerste bijdrage is van Vivian Bij de Vaate over de voorwaardelijke ontbinding. $\mathrm{Zij}$ annoteert het recente arrest van de Hoge Raad over de toelaatbaarheid van de voorwaardelijke ontbinding onder de $\mathrm{Wwz}$ en bespreekt in hoeverre de overwegingen van de Hoge Raad ook toepasbaar zijn op andere situaties dan het ontslag op staande voet, bijvoorbeeld wanneer het bestaan van een arbeidsovereenkomst wordt betwist. Ronald Beltzer en Simone Schmeetz analyseren de herplaatsingsverplichting in concern en komen tot de conclusie dat herplaatsing in het concern juridisch-dogmatisch problematisch kan zijn vanwege de verschillende verschijningsvormen van concerns. Het ene concern is het andere niet.

Chiraz Muradin behandelt het ontslag van managers en directeuren onder de Wwz. De bedenktermijn is juridisch doorgedacht door Hanneke Bennaars en Anita van Empel; in hun bijdrage geven zij onder meer antwoord op de vraag wanneer de termijn begint te lopen. Eylard van Fenema en Ans Looijenga bespreken het opvolgend werkgeverschap en tot slot bevat dit nummer een nieuw cijfermatig overzicht van een ontslagthema van Marit Beukhof en Rachel Rietveld.

Of de $\mathrm{Wwz}$ het vaste contract heeft verzwaard, valt te betwisten, maar voor werkgevers is het niet antrekkelijker geworden werknemers in vaste dienst te nemen. Mogelijk kiezen werkgevers dus nog steeds voor andere contractvormen dan het vaste contract teneinde kosten te drukken en risico's te beperken. Het vaste contract lijkt daarmee te zijn verworden tot een onbereikbaar statussymbool. Een effectieve anpak van doorgeschoten flexibilisering lijkt derhalve niet te kunnen zonder aan- 
pak van bestaande wet- en regelgeving en de modernisering van het vaste contract. Wat dit gaat betekenen voor het recent gewijzigde ontslagrecht zullen we moeten afwachten, maar een nieuwe wijziging is (op de lange termijn) niet uit te sluiten. Zeker is wel dat dit het nodige politieke kunst- en vliegwerk en gepolder zal vergen.

De redactie 